Research Article

\title{
Antiangiogenic and anticancer activity of saponins of Momordica cymbalaria
}

\author{
Raju Koneri, Nagarathna P. K. M., Mubasheera M. G.*, M. Madhu Mohan
}

\begin{abstract}
Department of Pharmacology, Karnataka College of pharmacy, Bangalore-560001, Karnataka, India
\end{abstract}

Received: 1 November 2013

Accepted: 13 November 2013

\section{*Correspondence to:}

Dr. Mubasheera M. G.,

Email: mubasheera595@gmail.com

(C) 2014 Koneri $\mathrm{R}$ et al. This is an open-access article distributed under the terms of the Creative Commons Attribution NonCommercial License, which permits unrestricted noncommercial use, distribution, and reproduction in any medium, provided the original work is properly cited.

\begin{abstract}
Background: The aim of the current study was to evaluate invitro anticancer activity of saponins of MC on EAC cells by using cytotoxicity (MTT) assay. To evaluate in vivo antiangiogenic potential of saponins of MC on rat air sac angiogenesis, EAC induced peritoneal angiogenesis, CAM angiogenesis.

Methods: MTT assay was carried out at different concentrations of saponins of MC in 12 microliter plates containing media with EAC cells. In rat air sac angiogenesis, carrageenin was injected (s.c.) into the air sac. Dexamethasone, indomethacin, saponins of MC was administered to identify the angiogenic activity. In EAC induced angiogenesis in peritoneum, EAC cells were administered through i.p in mice peritoneum. 5-fluoro uracil, (i.p) and saponins of MC (orally) was given to identify angiogenic activity. In CAM angiogenesis, erythropoietin was given to eggs on $8^{\text {th }}$ day of incubation. saponins were given on the $12^{\text {th }}$ day for two days to observe the antiangiogenic activity.

Results: The observed cytotoxic effects of saponins of MC on EAC cells find statistically significant. There is significant reduction in vascular branching in rat air sac model; EAC induced peritoneal angiogenesis, CAM model by the saponins of MC.

Conclusions: Due to lack of certain records, it is envisaged that the change of medicine both discontinuation as well as addition was done because of blood glucose control, cost factor [in case of pioglitazone] as well as patient's compliance.
\end{abstract}

Keywords: Ehrlich ascetic cells, Antiangiogenesis, Momordica cymbalaria, CAM, Air sac model, Erythropoietin, Carrageenin, MTT

\section{INTRODUCTION}

Cancer is a major public health burden in both developed and developing countries. The national cancer institute collected about 35,000 plants samples from 20 countries and has screened around 114,000 extracts for anticancer activity of the 92 anticancer drugs between 1983 and $1994,60 \%$ are of natural origin. ${ }^{1}$

The NCI in vitro primary screen consists of a panel of 60 different human tumor cell lines against which compounds are tested over a defined range of concentrations to determine the relative degree of growth inhibition or cytotoxicity against each cell line. The design and operation of the screen is such that, for each compound tested, both the absolute and relative sensitivities of individual cell lines comprising the screen are sufficiently reproducible that a characteristic profile or "fingerprint" of cellular response is generated. ${ }^{2}$

The Ehrlich tumor as a spontaneous murine mammary adenocarcinoma. It is a rapidly growing carcinoma with very aggressive behaviour and is able to grow in almost all mice strains.

It has been used as a transplantable tumour model to investigate the antineoplastic effects of several chemical compounds. After intraperitoneal inoculation of Ehrlich tumour cells, the ascetic volume and cells number increase drastically. This has been associated to an increase in peritoneal vascular permeability. ${ }^{3}$ 
Growth of solid tumor in both the primary and metastatic sites depends on angiogenesis the formation of new blood vessels, to nourish the tumour. In pioneering work by Folkman, cancer cells implanted in vascular sites in animals grew rapidly and formed large tumors. In contrast, cells implanted in vascular sites were unable to form tumour masses $1 \& 2 \mathrm{~mm}$ in size. This work led Folkman to hypothesize that angiogenesis was obligatory for tumour growth. ${ }^{4}$

Tumour angiogenesis has become an intensely investigated area over the last decade because it is an essential component of the growth and spread of cancer and is therefore potentially a therapeutic target. ${ }^{5}$

Antiangiogenesis has become one of the most exciting approaches in the development of cancer drugs. There is no doubt that blockage of tumor blood supply will be beneficial for cancer patients. Indeed, many available angiogenesis inhibitors have produced remarkable antitumor effects in animal models. However, it is uncertain if these angiogenesis inhibitors will produce similar effects in human cancer patients. Antiangiogenic therapy should be combined with chemotherapy, radiotherapy, or immune therapy to conquer human cancers ${ }^{6}$.Traditional herbal medicine has long been recognized as a potential source for discovering such agents. Indeed, many herbs and phytochemicals have been shown to have antiangiogenic activities both in vitro and invivo. $^{7}$

Momordica cymbalaria Fenzl (MC) (Cucurbitaceae) is a species used locally for the treatment of diabetes mellitus. ${ }^{8}$ The roots were reported for its anti-ovulatory and abortifacient ${ }^{9}$ and anti-implantation activities. ${ }^{10}$ Fruits of $\mathrm{MC}$ are also reported to have antimicrobial activity. ${ }^{11}$ Cardio-protective, ${ }^{12}$ antiulcer, ${ }^{13}$ antioxidant and hepatoprotective activities. ${ }^{14}$ The fruit powder and extracts of MC were previously reported to have Type 1 anti-diabetic activity in experimental diabetic models. ${ }^{15-17}$

\section{METHODS}

\section{Animals}

Adult Swiss albino mice (8-12 weeks, weighing $25 \pm 5 \mathrm{~g}$ ).

\section{Collection of plant material}

The fresh roots of MC were collected from Gadag district, Karnataka.

\section{Extraction of plant material}

Powdered leaves were subjected to successive extraction in a soxhlet extractor with methanol. The extract obtained was concentrated in a rotary shaker evaporator to dryness to get a constant weight.

\section{Preliminary phytochemical studies}

Methanolic extracts of were subjected to chemical tests for the identification of their active constituents.

\section{Acute Oral Toxicity Study}

Healthy female rats initially limit test is performed on a maximum of 5 animals with a test dose of $2000 \mathrm{mg} / \mathrm{kg}$. Starting with a dose of $5 \mathrm{mg} / \mathrm{kg}$ for one animal; if animal survive then dose for next animal in increased by factor of 3.2 times the dose.

\section{Materials and chemicals}

Cytotoxicity (MTT) assay

Cell lines used

\section{Reagents}

Trypsin $(0.25 \%+$ EDTA, $1 \mathrm{mM}$, in PBSA $)$

MTT Salt $(5 \mathrm{mg} / \mathrm{ml}$ in PBS)

Isopropanol

\section{Media}

Minimum essential medium(Eagle) with $2 \mathrm{mM} \mathrm{L}$ glutamine and Earle's BSS adjusted to contain $1.5 \mathrm{~g} / \mathrm{L}$ sodium bicarbonate, $0.1 \mathrm{~mm}$ non-essential amino acids, and $1.0 \mathrm{mM}$ Na pyruvate, $90 \%$; fetal calf serum, $10 \%$.

\section{Equipment}

Inverted microscope (Labomed, USA), Biosafety cabinet class II (Alfa Linear), CO2 incubator (Forma, Thermo Scientific, Micropipettes (Thermo Scientific), RO water system (Millipore)Surgical tape, Cover slip, Whatmann paper discs, sterile forceps, sterile needles, gloves, cotton, Scissors, Newbaur Chamber, WBC pipette, cover slip.

Chemical list for air sac model, chemical list for EAC induced peritoneal angiogenesis EAC cells, chemical list for Erythropoietin induced angiogenesis on CAM model and cytotoxicity (MTT) assay for EAC (Saponins of MC $10 \mathrm{mg} / \mathrm{ml}$ stock solution) were given (Table 1, 2, 3 and 4).

Table 1: Chemical list for air sac model.

\begin{tabular}{|lll|}
\hline \hline Sr. No. & Chemicals & Company \\
\hline 1. & Carragenin & Bharath chemicals \\
\hline 2 & Indomethacin & “ \\
\hline 3 & Dexamethasone & “ \\
\hline 4 & Carmine dye & " \\
\hline 5 & $\begin{array}{l}\text { Dihydro streptomycin } \\
\text { sulfate }\end{array}$ & Shushrutha medicals \\
\hline 6 & Penicillin G potassium & “ \\
\hline
\end{tabular}


Table 2: Chemical list for EAC induced peritoneal angiogenesis EAC cells.

\begin{tabular}{|lll|}
\hline Sr. No. & Chemicals & Company \\
\hline 1 & 5-fluoro uracil & Ramaya Medicals \\
\hline 2 & Tryphan blue & Hi media \\
\hline
\end{tabular}

Table 3: Chemical list for erythropoietin induced angiogenesis on CAM model.

\begin{tabular}{|lll|}
\hline S.No & Chemicals & Company \\
\hline 1 & Erythropoietin & Ramaya Medicals \\
\hline 2 & $70 \%$ ethanol & Bharath chemicals \\
\hline
\end{tabular}

Table 4: Cytotoxicity (MTT) assay for EAC (Saponins of $\mathrm{MC} 10 \mathrm{mg} / \mathrm{ml}$ stock solution).

\begin{tabular}{|llll|l|}
\hline & 1 & 2 & 3 & 4 \\
\hline A & Blank & Control & $\begin{array}{l}0.1 \mathrm{mg} \\
(10 \mu \mathrm{l})\end{array}$ & $\begin{array}{l}0.4 \mathrm{mg} \\
(40 \mu \mathrm{l})\end{array}$ \\
\hline \multirow{2}{*}{ B } & \multirow{2}{*}{ Blank } & Control & $\begin{array}{l}0.2 \mathrm{mg} \\
(20 \mu \mathrm{l})\end{array}$ & $\begin{array}{l}0.5 \mathrm{mg} \\
(50 \mu \mathrm{l})\end{array}$ \\
\hline \multirow{2}{*}{ C } & \multirow{2}{*}{ Blank } & $\begin{array}{l}0.05 \mathrm{mg} \\
(5 \mu \mathrm{l})\end{array}$ & $\begin{array}{l}0.3 \mathrm{mg} \\
(30 \mu \mathrm{l})\end{array}$ & $\begin{array}{l}1.0 \mathrm{mg} \\
(100 \mu \mathrm{l})\end{array}$ \\
\hline
\end{tabular}

MTT 3-(4, 5-dimethyl thiazol-2-yl)-2, 5-diphenyl tetrazolium bromide assay for EAC

\section{Plating out cells}

EAC cells were trypsinized, and the cells were collected in growth medium containing serum. The suspension $(5$ min at $200 \mathrm{~g}$ ) was centrifuged to pellet the cells. Resuspended the cells in growth medium, and were counted. $1 \times 10^{6}$ cells were plated to each well of a 12 -well microtiter plate. $1 \mathrm{ml}$ of the growth medium was added to each wells. First two wells (A1, B1 \& C1) were used as blank. The next two wells (A2 \& B2) were used as controls and incubated at $37^{\circ} \mathrm{C}$ overnight.

\section{Drug addition}

Serial dilutions of the saponins of MC were prepared in sterile Milli Q water to give different concentrations of drug $(0.05,0.1,0.2,0.3,0.4,0.5 \& 1 \mathrm{mg} / \mathrm{ml})$ from the stock solution $(10 \mathrm{mg} / \mathrm{ml})$. The EAC cells were feeded in each well in columns with $100 \mu$ l of fresh growth medium. The different drug concentration of Saponins of MC was added to all different wells other than blank and control. The plates were returned to incubate for 24 hours.

\section{Growth period}

At the end of the drug exposure period, the medium was removed from all the wells containing cells, and the cells were feeded with $200 \mu$ l of fresh medium.

Estimation of surviving cell numbers
The plate was feeded with $200 \mu \mathrm{l}$ of the fresh medium at

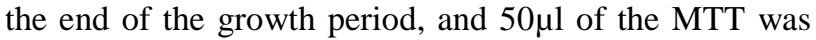
added to all the wells in columns and incubated them for $4 \mathrm{~h}$ at $37^{\circ} \mathrm{C}$. The medium and MTT from the wells was removed and the remaining MTT-Formosan crystals was dissolved by adding $200 \mu \mathrm{l}$ of acidified isopropanol to all of the wells in columns. The absorbance was recorded at $570 \mathrm{~nm}$ immediately, because the product is unstable.

$$
\% \text { cell inhibition }=100-\{(\text { At-Ab }) /(A c-A b)\} \times 100
$$

Where,

$\mathrm{At}=$ Absorbance value of test compound

$\mathrm{Ab}=$ Absorbance value of blank

$\mathrm{Ac}=$ Absorbance value of control

\section{Rat air sac model}

Induction of Air Pouch-Type Inflammation by carrageenin in Rats

Air pouch-type inflammation was induced by carrageenin drug the Male Sprague-Dawley rats, specific pathogenfree, weighing 160 to $170 \mathrm{~g}$ were lightly anesthetized with diethyl ether and $8 \mathrm{ml}$ of air was injected s.c. on the back to make an air pouch oval in shape.

After Twenty-four hours later, $4 \mathrm{ml}$ of a $2 \%(\mathrm{w} / \mathrm{v})$ solution of carrageenin in saline was injected into the air pouch under light diethyl ether anaesthesia. The carrageenin solution had been sterilized by autoclaving at $121^{\circ} \mathrm{C}$ for $15 \mathrm{~min}$ and supplemented with antibiotics [0.1 $\mathrm{mg}$ ] of penicillin $\mathrm{G}$ potassium and $0.1 \mathrm{mg}$ of dehydro streptomycin sulphate per millilitre of the solution] after cooling to $40-45^{\circ} \mathrm{C}$.

\section{Drug Treatment}

The test drug was dissolved in sterile distilled water, and the stranded drug indomethacin and dexamethasone were dissolved in $99.5 \%$ ethanol. Stock solutions were diluted with saline and $0.5 \mathrm{ml}$ of the diluted solution containing the indicated amount of drugs was injected into the pouch of each rat under light diethyl ether anaesthesia just after and 2 and 4 days after carrageenin injection. Final concentrations of ethanol in the saline solution were adjusted to $2 \%(\mathrm{v} / \mathrm{v})$. Control rats received the same amount of saline solution containing each vehicle at $2 \%$ $(\mathrm{v} / \mathrm{v})$.

\section{Determination of Angiogenesis in Granulation Tissue}

Angiogenesis in granulation tissue were carried out using carmine dye One, 3, and 6 days after the injection of carrageenin solution, $3 \mathrm{ml}$ of $5 \%(\mathrm{w} / \mathrm{v})$ carmine dye in $5 \%(\mathrm{w} / \mathrm{v})$ gelatine in saline at $37^{\circ} \mathrm{C}$ was injected into the tail vein of each rat under light diethyl ether anaesthesia. The carcasses were chilled on ice for $3 \mathrm{~h}$, and the entire granulation tissue was dissected and weighed. After being washed with PBS ( $\mathrm{pH} 7.4)$, granulation tissue was 
homogenized in 2 volumes of $0.5 \mathrm{mM}$ sodium hydroxide using a Vir-Tis 45 homogenizer for $4 \mathrm{~min}$ at scale 40 on an ice bed. The tissue homogenate was centrifuged at $10,000 \mathrm{~g}$ and $4^{\circ} \mathrm{C}$ for $30 \mathrm{~min}$. Five hundred microliters of the supernatant was diluted 2-fold with $0.5 \mathrm{mM}$ sodium hydroxide and centrifuged again at $14,000 \mathrm{~g}$ and $4^{\circ} \mathrm{C}$ for $30 \mathrm{~min}$. The dye content in $200 \mathrm{ml}$ of the supernatant was determined spectrophotometrically by measuring absorbance at $490 \mathrm{~nm}$. For the standard curve, known amounts of carmine dye were added to the final supernatant of granulation tissue of control rats that were injected with $3 \mathrm{ml}$ of a $10 \%(\mathrm{w} / \mathrm{v})$ gelatine solution in saline without carmine dye, and the absorbance determined. The amount of carmine dye in the whole granulation tissue was then calculated.

\section{Determination of Pouch Fluid Volume, and Granulation} Tissue Weight

1, 3, and 6 days after the injection of Carrageenin solution, the rats were sacrificed by cutting the carotid artery under diethyl ether anaesthesia. Total pouch fluid was collected and its volume measured. Three and 6 days after carrageenin injection, granulation tissue that formed was dissected and weighed.

\section{Ehrlich Ascites Induced Peritoneal Angiogenesis}

\section{Ehrlich Ascites Carcinoma (EAC)}

Animals were inoculated with $1 \times 10^{6}$ cells/mouse (i.p.) on day ' 0 ' and treatment with the drugs started $24 \mathrm{~h}$ after inoculation for a period of 14 days. The drugs (Saponins of MC) were dissolved in distilled water.

The Mice were divided into three groups (each group of 12 mice)

- Group 1: Normal control (Receives Normal saline $0.9 \% \mathrm{NaCl} w / \mathrm{v}$ )

- Group 2: Test group (Saponins of Momordica cymbalaria (175mg/kg;po;/day/10days)

- Group 3: Standard group (Receives Fluorouracil at a dose of $20 \mathrm{mg} / \mathrm{kg} / 10$ days)

Food and water were withheld $18 \mathrm{~h}$ before sacrificing the animals. On day 15 , half of the animals $(n=6)$ in each group were killed and the remaining animals were kept to observe the life span of the hosts.

A. Morphology of angiogenesis on peritoneum: Peritoneal lining of mice

B. Percentage increase life span (\% ILS):

$$
\% \mathrm{ILS}=[(\mathrm{T}-\mathrm{C}) / \mathrm{T}] * 100
$$

Where,

$\mathrm{T}=$ number of days the treated animals survived

$\mathrm{C}=$ number of days the control animals survived.

\section{Tumour cell count (EAC)}

The ascitic fluid was taken in a WBC pipette and diluted 100 times. Then a drop of the diluted cell suspension was placed on the Neubauer counting chamber and the number of cells in the 64 small squares was counted.

D. Viable/non-viable tumour cell count (EAC)

The cells were stained with trypan blue $(0.4 \%$ in normal saline) dye. The cells that did not take up the dye were viable and those that took the stain were nonviable. These viable and nonviable cells counted.

$$
\text { Cell count }=\frac{\text { No. of Cells } \mathrm{x} \text { Dilution }}{\text { Area } \mathrm{x} \text { Thickness of liquid film }}
$$

\section{E. Histopathological studies}

A portion of liver and kidney of animals in all groups were stored in container for 12 hours in $10 \%$ formalin solution and subjected to histopathological studies.

\section{Chick embryo CAM assay}

\section{Materials and methods}

Fertilized chicken eggs were incubated for 3 days at $37^{\circ} \mathrm{C}$. On day-3, eggs were swabbed with $70 \%$ alcohol under a laminar flow hood. Albumin (2-3 ml) was withdrawn using a syringe with a 21-gauge needle through the pointer end of the egg in order to allow detachment of the developing CAM from the eggshell. A window was then cut in the shell using a fine-cutting tool, and the shell was then removed with sterile forceps. This window served as a portal of access for the CAM. Filter paper discs with the test substances were placed directly using microsurgical forceps over a blood vessel, the CAM treated with rHuEpo an angiogenic response characterized by the presence of allantoic vessels spreading radially towards the disc. The experiments were performed between days 8 and 12 of incubation, because it is generally accepted that implants made from days 8 to 10 are strongly angiogenic. The filter disc dissolved in $2 \mathrm{ml}$ of PBS were implanted on the top of growing CAM under sterile conditions within a laminar flow hood.19 RHuEpo was delivered at 1.0-10.0 U/implant.

\section{RESULTS}

Data of preliminary qualitative analysis saponins of roots of Momordica cymbalaria was given (Table 5).

\section{Acute Oral Toxicity}

Mortality in the acute toxicity test of saponins of MC was seen in the limit test at the dose of $2000 \mathrm{mg} / \mathrm{kg}$. Mortality was not seen in the main step up to a dose of $1750 \mathrm{mg} / \mathrm{kg}$ 
and hence, $1 / 10$ of $1750 \mathrm{mg} / \mathrm{kg}(175 \mathrm{mg} / \mathrm{kg})$ was selected for the study.

\section{In Vitro Cytotoxicity assay of Saponins of MC on enrich ascitic cell lines}

Administration of saponins of MC in ascending order of concentration from $50 \mu \mathrm{g}$ to $2000 \mu \mathrm{g}$ to Ehrlich ascitic cells in cytotoxicity (MTT) assay decreased cell viability and increased the percentage inhibition.

Table 5: Preliminary qualitative analysis saponins of roots of Momordica cymbalaria.

\begin{tabular}{|lll|}
\hline Sr. No. & Test & Present $(+)$ or absent $(-)$ \\
\hline 1 & Alkaloids & Negative \\
\hline 2 & Carbohydrates & Positive \\
\hline 3 & Glycosides & Positive \\
\hline 4 & Fixed oils \& fats & Negative \\
\hline 5 & $\begin{array}{l}\text { Gums \& } \\
\text { mucilage }\end{array}$ & Negative \\
\hline 6 & $\begin{array}{l}\text { Proteins \& } \\
\text { amino acids }\end{array}$ & Negative \\
\hline 7 & Saponins & Positive \\
\hline 8 & Tannins & Negative \\
\hline 9 & Phytosterols & Positive \\
\hline 10 & Flavonoids & Negative \\
\hline
\end{tabular}

Data of percentage of viability, inhibition of EAC to various concentrations of saponins of MC was given
(Table 6). Graph showing percentage of viability, inhibition of Ehrlich ascitic cells to various concentrations of saponins of MC (Figure 1).

Table 6: Percentage of viability, inhibition of EAC to various concentrations of saponins of $\mathrm{MC}$.

\begin{tabular}{|llll|}
\hline $\begin{array}{l}\text { Conc. } \\
(\mu g)\end{array}$ & $\%$ Viability & $\%$ Inhibition & Absorbance \\
\hline 50 & 97.90 & 02.10 & 1.4 \\
\hline 100 & 85.31 & 14.69 & 1.22 \\
\hline 200 & 44.55 & 55.45 & 0.637 \\
\hline 300 & 29.58 & 70.42 & 0.423 \\
\hline 400 & 8.32 & 91.68 & 0.119 \\
\hline 500 & 4.83 & 95.17 & 0.069 \\
\hline 1000 & 4.55 & 95.45 & 0.065 \\
\hline Control & 100.00 & 0.00 & 1.43 \\
\hline
\end{tabular}

The IC 50 of Saponins of Momordica cymbalaria in EAC was found to be $180 \mu \mathrm{g}$.

Data of effect of saponins of $\mathrm{MC}(175 \mathrm{mg} / \mathrm{kg}$; po; /day/2days) on carrageenin induced angiogenesis in male rats was given (Table 7). Graph showing effect of saponins of MC $(175 \mathrm{mg} / \mathrm{kg}$; po; /day/2days $)$ on carrageenin induced angiogenesis the measurement of pouch fluid volume in male rats (Figure 2).

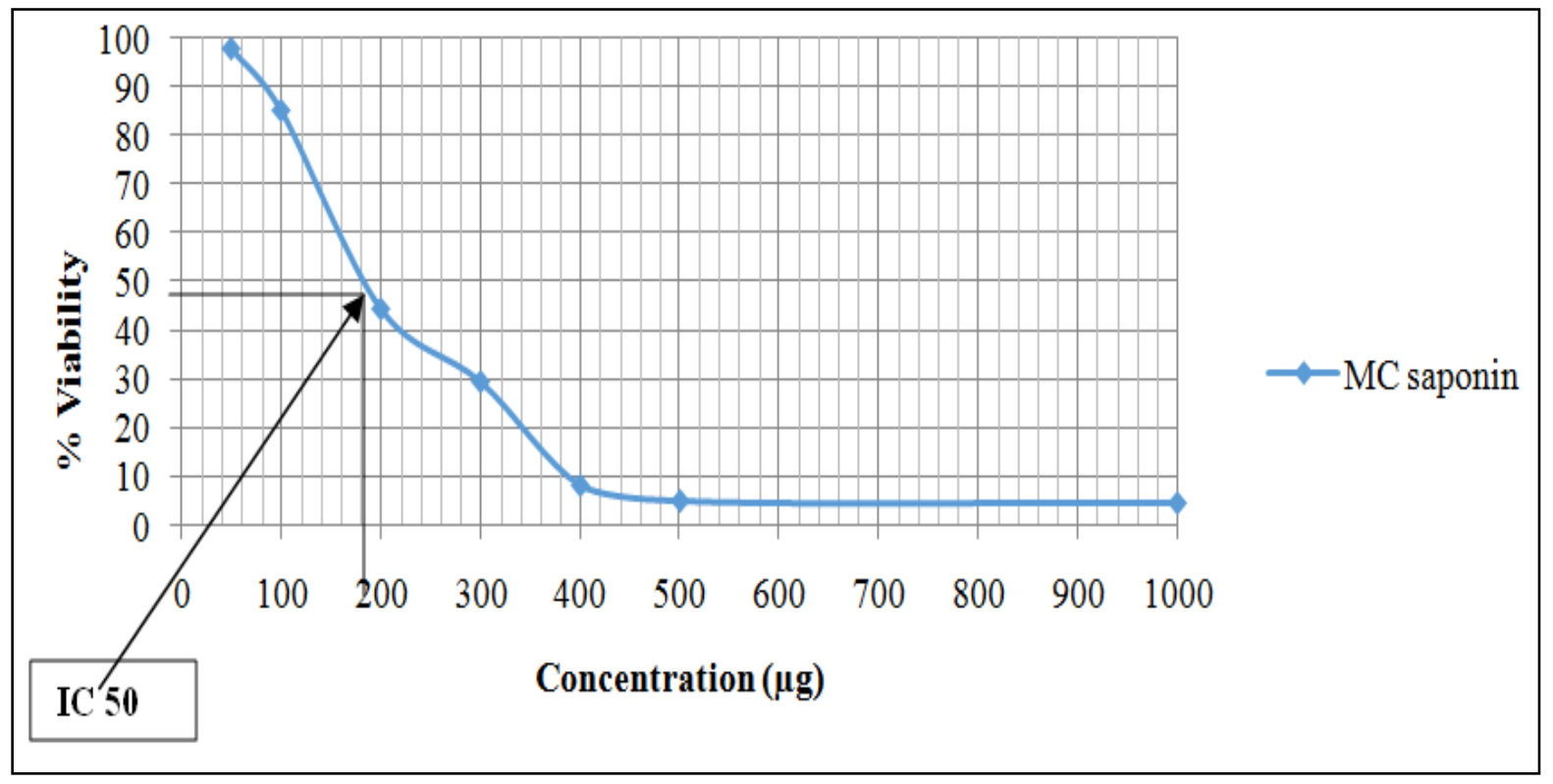

Figure 1: Showing percentage of viability, inhibition of Ehrlich ascitic cells to various concentrations of saponins of MC. 
Table 7: Effect of saponins of MC (175mg/kg; po; /day/2days) on carrageenin induced angiogenesis in male rats.

\begin{tabular}{|c|c|c|c|c|}
\hline Sr. No. & Groups & $\begin{array}{l}\text { Pouch fluid } \\
\text { volume (ml) }\end{array}$ & $\begin{array}{l}\text { Granulation } \\
\text { tissue weight (mg) }\end{array}$ & $\begin{array}{l}\text { Carmine dye } \\
\text { content (mg/tissue) }\end{array}$ \\
\hline 1 & $\begin{array}{l}\text { Carrageenin } \\
(4 \mathrm{ml}, 2 \%(\mathrm{w} / \mathrm{v}) \text { s.c } / \text { day }\end{array}$ & $0.500 \pm 0.036$ & $0.711 \pm 0.037$ & $36.17 \pm 0.3073$ \\
\hline 2 & $\begin{array}{l}\text { Carrageenin } \\
(4 \mathrm{ml}, 2 \%(\mathrm{w} / \mathrm{v}) \text { s.c /day }+ \text { Indomethacin } \\
{[100 \mu \mathrm{g} / \mathrm{rat} . \mathrm{sc} / \text { day/2days }]}\end{array}$ & $0.300 \pm 0.036^{* * *}$ & $0.246 \pm 0.009^{* * *}$ & $15.67 \pm 1.085^{* * *}$ \\
\hline 3 & $\begin{array}{l}\text { Carrageenin } \\
(4 \mathrm{ml}, 2 \%(\mathrm{w} / \mathrm{v}) \mathrm{s.c} / \mathrm{day}+ \\
\text { Dexamethasone }[10 \mu \mathrm{g} / \mathrm{ratsc} / \text { day/2days }]\end{array}$ & $0.000 \pm 0.000^{* * *}$ & $0.110 \pm 0.003^{* * *}$ & $11.17 \pm 0.4773^{* * *}$ \\
\hline 4 & $\begin{array}{l}\text { Carrageenin } \\
(4 \mathrm{ml}, 2 \%(\mathrm{w} / \mathrm{v}) \mathrm{s.c} / \mathrm{rat} / \mathrm{day}+\text { Saponins of MC } \\
{[175 \mathrm{mg} / \mathrm{kgsc} / \text { day } / 2 \text { days }]}\end{array}$ & $0.033 \pm 0.021^{* * *}$ & $0.1567 \pm 0.004^{* * *}$ & $13.83 \pm 0.3073^{* * *}$ \\
\hline
\end{tabular}

Values are expressed in Mean \pm SEM. $* * * \mathrm{P}<0.001$ when compared to control group

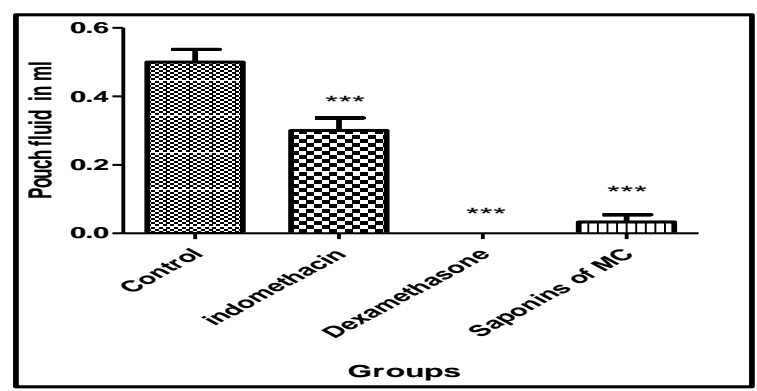

Figure 2: Effect of saponins of MC (175mg/kg; po; /day/2days) on carrageenin induced angiogenesis the measurement of pouch fluid volume in male rats.

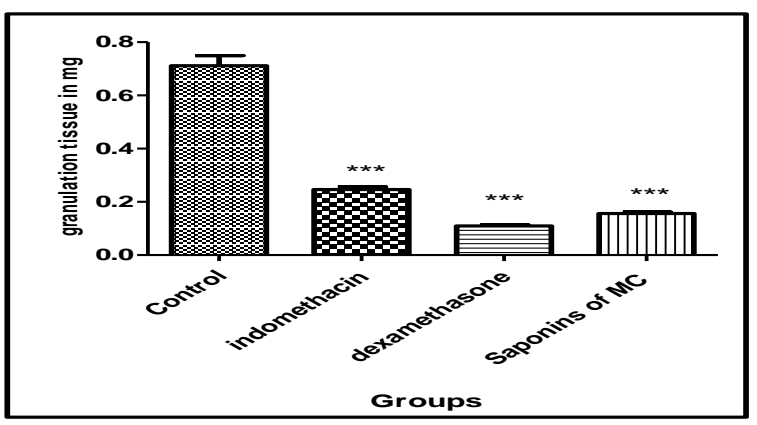

Figure 3: Effect of saponins of MC

(175mg/kg;po;/day/2days) on carrageenin induced angiogenesis the measurement of granulation tissue weight in male rats.

Values are expressed in Mean \pm SEM. ${ }^{* * *} \mathrm{P}<0.001$ when compared to control group

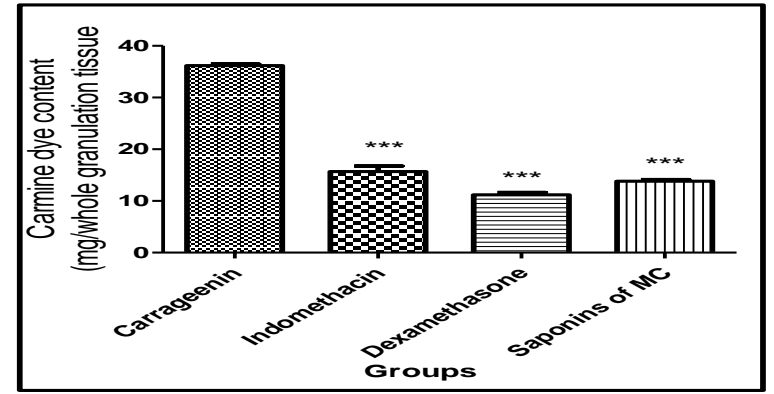

Figure 4: Effect of saponins of MC

(175mg/kg;po;/day/2days) on carrageenin induced angiogenesis the measurement of carmine dye content in male rats.

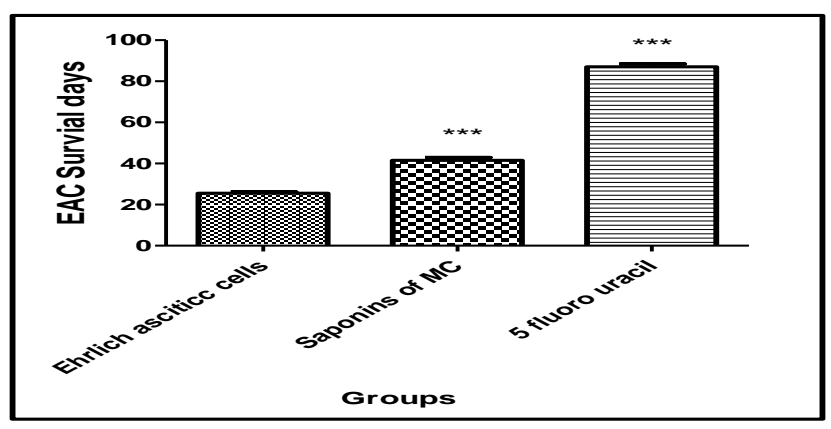

Figure 5: Effect of normal saline (0.2 ml.ip/days/10days); saponins of MC (175mg/kg;po;/day/10days); 5 fluoro uracil (20mg/kg.ip/day/10days) on EAC induced peritoneal angiogenesis.

Values are expressed in Mean \pm SEM. $* * * \mathrm{P}<0.001$ when compared to control group 
Table 8: Effect of normal saline (0.2 ml. ip/days/10days); saponins of MC (175mg/kg;po;/day/10days); 5 fluoro uracil (20mg/kg.ip/day/10days) on EAC induced peritoneal angiogenesis in female mice.

\begin{tabular}{|c|c|c|c|c|c|c|}
\hline Sr. No. & Groups & Dose & Effect on survival time & Body weight & Total cell count & viable cell count \\
\hline 1 & $\begin{array}{l}\text { Ehrlich } \\
\text { ascitic } \\
\text { cells }\end{array}$ & $\begin{array}{l}1 \times 10^{6} \\
\text { cells i.p }\end{array}$ & $25.500 \pm 0.670$ & $69.000 \pm 1.125$ & $2.882 \pm 0.025$ & $86.630 \pm 1.819$ \\
\hline 2 & $\begin{array}{l}\text { 5-fluoro } \\
\text { uracil pre- } \\
\text { treated } \\
\text { with } \\
\text { Ehrlich } \\
\text { ascetic ells }\end{array}$ & $\begin{array}{l}20 \mathrm{mg} / \mathrm{kg} / \\
\text { mice } / 10 \\
\text { days, i.p } \\
+1 \times 10^{6} \\
\text { cells i.p }\end{array}$ & $87.000 \pm 1.461^{* * *}$ & $30.330 \pm 0.714^{* * *}$ & $1.285 \pm 0.058^{* * *}$ & $12.550 \pm 0.451^{* * *}$ \\
\hline 3 & $\begin{array}{l}\text { Saponins } \\
\text { of MC pre- } \\
\text { treated } \\
\text { with } \\
\text { Ehrlich } \\
\text { ascetic } \\
\text { cells }\end{array}$ & $\begin{array}{l}175 \mathrm{mg} / \mathrm{k} \\
\mathrm{g} / \text { day for } \\
\text { two days, } \\
\text { orally }+ \\
1 \times 10^{6} \\
\text { cells i.p }\end{array}$ & $41.500 \pm 1.478^{* * *}$ & $47.830 \pm 1.302^{* * *}$ & $2.147 \pm 0.018^{* * *}$ & $69.200 \pm 1.474^{* * *}$ \\
\hline
\end{tabular}

Values are expressed in Mean \pm SEM. $* * * \mathrm{P}<0.001$ when compared to control group

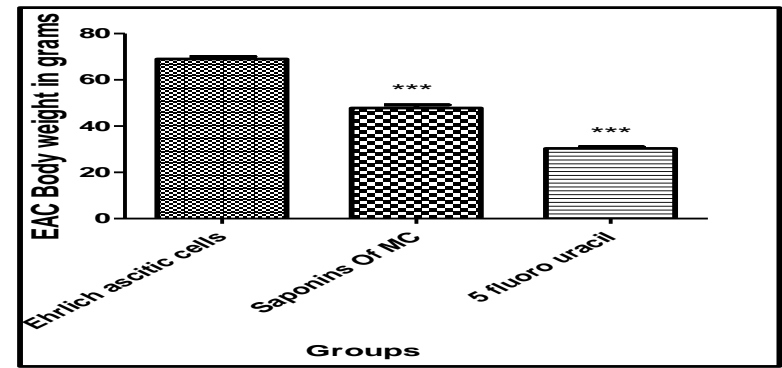

Figure 6: Effect of normal saline $(0.2$ ml.ip/days/10days); saponins of MC (175mg/kg; po; /day/10days); 5 fluoro uracil (20mg/kg.ip/day/10days) on EAC induced peritoneal angiogenesis body weight of the animals.

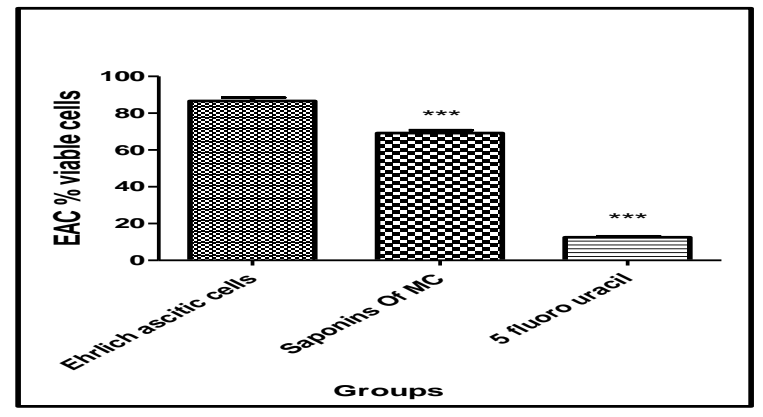

Figure 7: Effect of normal saline $(0.2 \mathrm{ml}$. ip/days/10days); saponins of MC

(175mg/kg;po;/day/10days); 5 fluoro uracil (20mg/kg.ip/day/10days) on EAC induced peritoneal angiogenesis viable cell count.

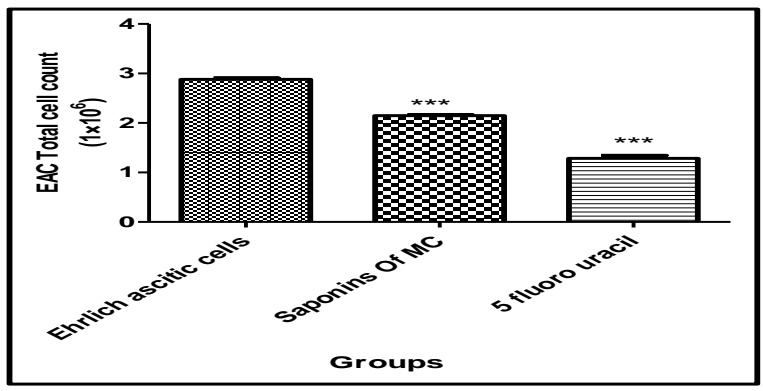

Figure 8: Effect of normal saline $(0.2$ ml.ip/days/10days); saponins of MC (175mg/kg; po; /day/10days); 5 fluoro uracil (20mg/kg.ip/day/10days) on EAC induced peritoneal angiogenesis total cell count.

Values are expressed in Mean \pm SEM. ***P $<0.001$ when compared to control group

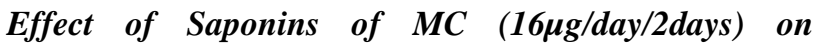
Erythropoietin induced angiogenesis in chick embryo CAM assay.

Administration of erythropoietin [30units/day/4days] into the eggs on $8^{\text {th }}$ incubation day for 4 days showed the formation of vasculature branching. Administration of saponins of MC $(32 \mu \mathrm{g} /$ day/2days $)$ into the eggs on $12^{\text {th }}$ day after the administration of erythropoietin [30units/day/4days] for two days decreased the vascular formation. 


\section{DISCUSSION}

Natural products have long been used to prevent and treat diseases including cancers and might be good candidates for the development of anti-cancer drugs. In this study, the cytotoxicity of saponins of MC on EAC in vitro was examined by MTT assay.

The present study provides evidence that Saponins of MC may act as a potent growth inhibitory compound in EAC. EAC were more sensitive to Saponins of MC treatment with an IC50 at a concentration of [180 $\mu \mathrm{g}]$.

It is reported that carrageenin-induced inflammation in air pouch in rats, COX-2-derived PGE2 plays a role in angiogenesis in the developing chronic granulation tissue. The quantitative analysis of angiogenesis in granulation tissue was carried out using carmine dye. The increase in dye content in granulation tissue correlates with the increase in the capillary density. From the determination of dye content in granulation tissue and histological analysis, it is concluded that the COX-2 inhibitor Momordica cymbalaria of Saponins inhibits angiogenesis in granulation tissue as well as inflammatory response.

By inhibiting COX-2 in experimental cancers that over express this enzyme, the balance between angiogenic and anti-angiogenic signals, which control VEGF (vascular endothelial growth factor), expression and angiogenesis, can be restored, causing tumour necrosis and tumour regression to a small, dormant state.

In present study of Rat air sac model, dexamethasone, strongly inhibited the accumulation of pouch fluid, leukocyte infiltration into pouch fluid, and formation of granulation tissue. Although dexamethasone reduced granulation tissue weight more potently than saponins of MC and indomethacin. saponins of MC significantly reduced granulation tissue weight, pouch fluid, dye content. Thus showing antiangiogenic property.

Anti-angiogenic strategies aimed at inhibition of endothelial cell proliferation, interference with endothelial cell adhesion and migration, and interference with metalloproteinase are currently emerging. In the present study, the anti-angiogenic activity of Momordica cymbalaria root (Saponins) extracts and its fractions was evaluated in vivo using the chick embryo chorioallantoic membrane (CAM) assay. CAM offers the advantage of being simple to use and low cost. Moreover, the vascular system of CAM is directly accessible to observation and experimentation, and there are no metabolic or hormonal influences. Quantification of vascular changes in the CAM in response to inhibition of angiogenesis was simplified by comparing the image of CAM vessels with or without the administration of the test substances. The different qualitative changes in the capillaries for each test substances were observed and used to quantify the anti- angiogenc effects of Momordica cymbalaria root extracts saponins.

In the present study of CAM model, erythropoietin increased vasculature branching in eggs and the saponins of MC reduced the vascular branching which shows the antiangiogenic property.

\section{CONCLUSION}

Cytotoxic effects of saponins of MC on Ehrlich ascetic cells were observed and the $\mathrm{IC}_{50}$ value by MTT assay was found to be $180 \mu \mathrm{g}$. The results indicate that saponins of $\mathrm{MC}$ are having anticancer activity. Further studies will be needed to evaluate the mechanism involved in the anticancer activity of saponins of MC.

\section{ACKNOWLEDGEMENTS}

The authors are thankful to the Department of Pharmacology, Karnataka college of Pharmacy, Bangalore, Karnataka, India.

Funding: No funding sources Conflict of interest: None declared

Ethical approval: Approval was taken from the institutional animal ethics committee

\section{REFERENCES}

1. Shoeb M. Anticancer agents from medicinal plants. Bangladesh J Phamacol. 2006;1:35-41.

2. Michael R, Boyd, Kenneth D, Paull. Some Practical Considerations and Applications of the National Cancer Institute In vitro Anticancer Drug Discovery Screen Drug development research.1995;34:91-109.

3. Sheela M. Lingaraju, Keshavaiah K, Salimath BP. Inhibition of in vivo angiogenesis by Anacardiumoccidentale L. involves repression of the cytokine VEGF gene expression. Drug Discov Ther 2008;2(4):234-44.

4. Folkman J. Tumor angiogenesis. Therapeutic implications. N Engl J Med. 1971;285:1182-6.

5. Tortora G, Melisi D, Ciardiello F. Angiogenesis: A target foe cancer therapy. Curr Pharma Design. 2004;10:11-26.

6. Aisha A, M. Abu-Salah K, Ismail Z, Abdul Majid A. Screening for Antiangiogenesis Activity in Natural Products: A Review. Webmed Central Pharmacology. 2010;1(12):WMC001315.

7. Cardenas C, Quesada AR, Medina MA. Evaluation of the angiogenic effect of aloe-emodin. Cell Mol Life Sci. 2006;63:3083-9.

8. Koneri R, Saraswati CD, Balaraman R, Ajeesha EA. Antiimplantation activity of the ethanolic root extract of Momordica cymbalaria Fenzl in rats. Indian $\mathbf{J}$ Pharmacol. 2007;9:90-6. 
9. Swamy VBM, Jayaveera KN. Antimicrobial properties of Momordica cymbalaria hook. F.Pharmacologyonline. 2007;3:505-10.

10. Koneri R, Balaraman R, Hariprasad, Vinoth Kumar M, Ali A. Cardioprotective effect of Momordica Cymbalaria fenzl in rats with Isoproterenol-induced myocardial injury. Journal of Clinical and Diagnostic Research. 2008;2:699-705.

11. Dhasan PB, Jegadeesan M, Kavimani S. Antiulcer activity of aqueous extract of fruits of Momordica cymbalaria hook f. in wistar rats. Phcog Res. 2010Jan;2(1):58-61.

12. Kumar P, DevalRao G, Lakshmayya, Ramachandra SS. Antioxidant and hepatoprotective activity of tubers of Momordica tuberose Cogn. Against $\mathrm{CCl}_{4}$ induced liver injury in rats. Indian $\mathrm{J}$ Exp Biol. 2008Jul;46:510-13.

13. Kameswara Rao B, Kesavulu MM, Giri R, AppaRao $\mathrm{CH}$. Antidiabetic and hypolipidemic effects of Momordica cymbalaria Hook. Fruit powder in alloxan-diabetic rats. Journal of Ethnopharmacology. 1999;67:103-9.
14. KameswaraRao B, Kesavulu MM, AppaRao CH. Antihyperglycemic activity of Momordica cymbalaria in alloxan diabetic rats. Journal of Ethnopharmacology. 2001;78:67-71.

15. Rajasekhar MD, Kameswara Rao B, Kumar KV, RameshBabu K,Sameena SF, Sampath Kumar MT et al. Isolation and characterization of a novel antihyperglycemic protein from the fruits of Momordica cymbalaria. Journal of Ethnopharmacology. 2010;128:58-62.

16. Vijayabaskaran M, Yuvaraj KR, Saravanakumar M, Abhenaya K. Evaluation of invitro cytotoxic activity of ethanolic extract of Symplocos racemosa Roxb. International Journal of Pharmaceutical and Clinical Research. 2010;2(1):28-30.

17. Marcsek Z, Kocsis Z, Jakab M, Szende, Tompa A. The Efficacy of Tamoxifen in Estrogen ReceptorPositive Breast Cancer Cells Is Enhanced by a Medical Nutriment. Cancer Biother Radiopharm. 2004;19(6):746-53.

doi:10.5455/2319-2003.ijbcp20140206

Cite this article as: Koneri R, Nagarathna PKM, Mubasheera MG, Madhu Mohan M. Antiangiogenic and anticancer activity of saponins of Momordica cymbalaria. Int J Basic Clin Pharmacol 2014;3:70-8. 